\title{
EXCHANGE OF CAPTIVES WITHIN THE FRAMEWORK OF THE TRUCE OF DEULINO
}

\author{
Tomasz Bohun \\ "Mówią Wieki”(Centuries Speak) Magazine, Warsaw, Poland
}

\begin{abstract}
Introduction. The article investigates the issue of the exchange of captives between Russia and the Polish-Lithuanian Commonwealth after the Truce of Deulino conclusion on December 1 (11), 1618. This truce marked the end of the Time of Troubles in the Moscow State and established peaceful relations between Russia and the Polish-Lithuanian Commonwealth for 14 years. The author analyzes the circumstances of the exchange of captives, and also highlights main problems arising in the course of implementing the agreements. Materials. The study uses unpublished documents of the Ambassadorial Prikaz: record lists, petitions, lists of contract records stored in the form of columns and books in the Russian State Archive of Ancient Documents in funds No. 79 "Relations with Poland" and No. 141 "Prikaz Affairs of Old Years". Results. The Truce of Deulino provided the solution of two urgent issues: transfer of seven border cities and their uezds with subsequent delimitation of the border and exchange of captives. Over the course of time, the first agreements were reached only partly. Admittedly, castles smoothly passed to the Polish-Lithuanian possession, but because of mutual claims the border at the Trubchevsk-Novgorod-Seversk-Bryansk and the Vitebsk-Toropets lines became the part of the Treaty of Polyanovka (1634), which put an end to the Smolensk war. There were problems with the exchange of captives as well, which occurred more than three months later. However, the only culprit here was the Polish-Lithuanian side.

Key words: the Truce of Deulino, 1618, history of Russia, the Polish-Lithuanian Commonwealth, $17^{\text {th }}$ century, exchange of captives.

Citation. Bohun T. Exchange of Captives Within the Framework of the Truce of Deulino. Vestnik Volgogradskogo gosudarstvennogo universiteta. Seriya 4, Istoriya. Regionovedenie. Mezhdunarodnye otnosheniya [Science Journal of Volgograd State University. History. Area Studies. International Relations], 2019, vol. 24, no. 2, pp. 175-183. (in Polish). DOI: https://doi.org/10.15688/jvolsu4.2019.2.15
\end{abstract}

УДК 94(470)“1618”:355.415.8

Дата поступления статьи: 07.12.2018

ББК 63.3(2)44-68

Дата принятия статьи: 19.03.2019

\section{ОБМЕН ПЛЕННЫМИ В РАМКАХ ДЕУЛИНСКОГО ПЕРЕМИРИЯ}

\author{
Томаш Бохун \\ журнал «Говорят столетия» («Mówią wieki»), г. Варшава, Республика Польша
}

\begin{abstract}
Аннотация. Введение. В статье исследован вопрос обмена военнопленными между Россией и Речью Посполитой после заключения Деулинского перемирия 1 (11) декабря 1618 года. Это перемирие ознаменовало окончание Смутного времени в Московском государстве и установило мирные отношения между Россией и Речью Посполитой на 14 лет. Автор провел анализ обстоятельств обмена пленными, а также выделил основные проблемы, которые возникли в ходе реализации договоренностей. Материалы. В качестве источников в исследовании использованы неопубликованные документы Посольского приказа: статейные списки, челобитные, списки договорных записей, хранящиеся в виде столбцов и книг в Российском государственном архиве древних актов в фондах № 79 «Сношения с Польшей» и № 141 «Приказные дела старых лет». Результа$\stackrel{f}{\mathrm{~m} b l . ~ Д е у л и н с к о е ~ п е р е м и р и е ~ п р е д у с м а т р и в а л о ~ р е ш е н и е ~ д в у х ~ т е к у щ и х ~ в о п р о с о в: ~ п е р е д а ч у ~ с е м и ~ п р и г р а н и ч-~}$ ных городов и их уездов с последующей делимитацией границы и обмен военнопленными. Со временем была достигнута только часть первых договоренностей. По общему признанию, замки плавно перешли в () польско-литовское владение, но из-за взаимных притязаний граница на Трубчевско-Новгородско-Северско-
\end{abstract}


Брянской линии и Витебско-Торопецкой стала частью Поляновского мира (1634 г.), положившего конец Смоленской войне. Проблемы были также с обменом пленными, который произошел с опозданием более чем на три месяца. Здесь, однако, единственным виновником была польско-литовская сторона.

Ключевые слова: Деулинское перемирие, 1618 г., история России, Речь Посполитая, XVII в., обмен пленными.

Цитирование. Бохун Т. Обмен пленными в рамках Деулинского перемирия // Вестник Волгоградского государственного университета. Серия 4, История. Регионоведение. Международные отношения. - 2019. T. 24, № 2. - С. 175-183. - (На польском). - DOI: https://doi.org/10.15688/jvolsu4.2019.2.15

\title{
WYMIANA JEŃCÓW W RAMACH ROZEJMU DYWILIŃSKIEGO
}

\author{
Tomasz Bohun \\ Mówią wieki, Warszawa, Rzeczpospolita Polska
}

\begin{abstract}
Adnotacja. Rozejm dywiliński przewidywał rozwiązanie dwóch bieżących kwestii: przekazania Rzeczpospolitej siedmiu pogranicznych miast z powiatami wraz z późniejszą delimitacją granicy, oraz wymiany jeńców. Terminowo udało się zrealizować jedynie czesść pierwszego z ustaleń. Wprawdzie grody płynnie przeszły w polsko-litewskie władanie, jednak z powodu obustronnej obstrukcji do wytyczenia granicy na odcinkach trubczewsko-nowogrodzkosiewiersko-briańskim oraz wielisko-toropieckim doszło dopiero w ramach wieńczącego wojnę smoleńską pokoju polanowskiego. Problemy były też z wymianą jeńców, do której doszło z ponad trzymiesięcznym opóźnieniem. Tutaj jednak jedynym winowajcą była strona polsko-litewska.

Slowa kluczowe: Rozejm Deulinskiego, 1618, historia Rosji, Państwo polsko-litewskie, XVII wiek, wymiana jeńców.

Citation. Bohun T. Wymiana Jeńców w Ramach Rozejmu Dywilińskiego. Vestnik Volgogradskogo gosudarstvennogo universiteta. Seriya 4, Istoriya. Regionovedenie. Mezhdunarodnye otnosheniya [Science Journal of Volgograd State University. History. Area Studies. International Relations], 2019, vol. 24, no. 2, pp. 175183. DOI: https://doi.org/10.15688/jvolsu4.2019.2.15
\end{abstract}

Do końca marca 1619 roku Rosjanie rozliczyli się z polsko-litewskimi komisarzami i przekazali im klucze miejskie w kolejności Nowogródka Siewierskiego, Trubczewska, Krasnego Gorodiszcza, Siebieża, Newla, Staroduba i Poczepu [1, л. 1-66]. Można powiedzieć, że traktatowo w tym zakresie prawie wszystkie procedury zostały dotrzymane. Prawie, bo w Newlu doszło do zatargu między polskolitewskimi komisarzami Jerzym Siwickim i Iwanem Mieszczerinowem a moskiewskimi Maksymem Radiłowem i Fiłatem Domaszniewym na tle procedury przekazywania miasta. Rzecz w tym, że jeszcze przed przejęciem Newla przez stronę polsko-litewską nastapił eksodus jego mieszkańców. Do Pskowa i w jego okolice wymaszerował nie tylko garnizon strzelców i kozaków, uwożąc dużą część uzbrojenia i amunicji, ale także miejscowi duszpasterze z przybytkiem świątynnym, kupcy i ludność służebna. Zgodnie z traktatem rozejmowym zbrojni i duchowni musieli opuścić miasto, cywilom zaś pozostawiono prawo wyboru władcy. Tyle że miało to nastąpić po przekazaniu miasta Rzeczpospolitej. Ostatecznie polsko-litewscy komisarze przyjęli bałamutna argumentację Moskwicinów, że Newel zasiedlali tylko strzelcy z kozakami oraz duchowieństwo, zaś ludność służebna spełniała swoje powinności dochodząc do miasta z okolicznych wsi. Warunkiem zakończenia procedury przekazania Newla Rzeczpospolitej był zwrot przez stronę moskiewską wywiezionego uzbrojenia i ruchomości cerkiewnych [1, л. 47-61]. Nigdy do tego nie doszło.

Tak czy inaczej, owe zgoła błyskawiczne przekazanie przez Rosjan miast pogranicznych miało zasadniczy cel: uniknięcie incydentów, które strona polsko-litewska mogła użyć jako pretekstu do opóźnienia wymiany jeńców. Ich pośpiech był w pełni zrozumiały: w polskiej niewoli przebywał ojciec cara - metropolita Filaret Nikytycz.

Wedle postanowień traktatowych do wymiany jeńców miało dojść 25 lutego 1619 roku na rubieży dorohobusko-wiaziemskiej [4, л. 27 об. -28 об.]. Delegacja moskiewska wielcy posłowie, bojarzy Fiodor Szeremietiew i 
książę Daniło Mezecki, oraz okolniczy Artiemiej Izmaiłow i diacy Iwan Bołotnikow i Matwiej Somow - wraz z pierwszą grupa jeńców na czele ze starostą chmielnickim Mikołajem Strusiem, byłym komendantem garnizonu moskiewskiego, przybyła do Możajska w połowie lutego [6, л. 21]. Było to 185-190 osób (wątpliwości pozostawia kwalifikacja pięciu osób): 35 żołnierzyszlachciców - m.in. rotm. Piotr Chocimirski, kpt. Szymon Charliński oraz szkocki najemnik kpt. Aleksander Leslie - i w przeważającej większości służba oraz rzemieślnicy (m.in. szewcy, krawcy, rymarze, kucharze, cyrulicy i in. ,złote rączki”), a także trzech kapelanów-bernardynów ze służbą. $\mathrm{W}$ grupie były również kobiety (cztery wdowy i jedenaście mężatek) oraz ośmioro dzieci [6, л. 21 об.-22 об., 24 об.-25 об., 90-92]. Туlе pozostało z pułku, który w 1612 roku liczył ok. 800 żołnierzy (nie licząc cywilów). Przy czym tak duża strata w jego liczebności najpewniej nie była efektem mordów na podkomendnym Strusia po kapitulacji. Skądinąd wiadomo, że dworianie księcia Pożarskiego nie pastwili się na tą grupa jeńców. Z pewnością krwawe żniwo pociągnęly za sobą straty bojowe i niebojowe - katastrofalny głód na Kremlu jesienią 1612 roku - a także, być może, gehenna niewoli.

$\mathrm{Na}$ początku marca wielcy posłowie przenieśli się do Wiaźmy, zaś grupa jeniecka Strusia dołączyła do nich 17 marca [6, л. 21]. W tym czasie Moskwicini bezskutecznie próbowali nawiązać kontakt $\mathrm{z}$ komendantem Smoleńska, starostą mozyrskim Baltazarem Strawińskim, aby wyjaśnić przyczynę opóźnienia w wymianie: ich gońcy docierali tylko do Dorohobuża, skąd bezceremonialnie cofał ich tamtejszy wojewoda, renegat moskiewski Ławrientij Korsakow [6, л. 7-7 об., 16 об.]. Wielcy posłowie nie zasypiali gruszek w popiele: dzięki aktywnej działalności wywiadowczej szybko rozeznali się w sytuacji najważniejszych więźniów i jeńców w polsko-litewskiej niewoli, a więc metropolity Filareta, księcia Wasyla Golicyna i diaka Tomiły Ługowskiego oraz wojewody smoleńskiego Michaiła Szeina z żoną i trzema synami. Już w pierwszej połowie marca doszła ich informacja o śmierci księcia Golicyna, który zmarł $\mathrm{z}$ przyczyn naturalnych $\mathrm{w}$ Wilnie na przełomie stycznia i lutego 1619 roku [6, л. 27-30].

Nadzieje w zdobywaniu informacji o sytuacji Filareta wiązali także z Andreasem Fengerem,
Niemcem inflanckim, gońcem hetmana Chodkiewicza, czasowo oddelegowanym do personelu poselskiego Strawińskiego. Jego misja do Wiaźmy, w trzeciej dekadzie marca, zapowiadała sięnader obiecująco. Szeremietiewowi i Mezeckiemu, dzięki hojnym upominkom w postaci 10 par sobolich futer - udało się nakłonić go do współpracy: wobec informacji, że Filaret, Szein z rodziną oraz diak Ługowski niebawem mają zostać przywiezieni do Orszy, Fenger zobowiązał się do udzielenia pomocy Iwanowi Korotniewowi gońcowi wielkich posłów - w dotarciu do nich, $\mathrm{i}$ ujrzeniu „oczu czcigodnego ojca cara”. Plan ten pokrzyżował Korsakow, który gońca moskiewskiego cofnął do Wiaźmy, a Fengera ordynarnie zwymyślał i ,бил по щекам неведают про что (...)" [6, л. 20-21, 110-112 об., 140 об. $-141,156]$.

Wobec polsko-litewskiej obstrukcji Moskwicini opóźnili przetransportowanie z Moskwy drugiej grupy jeńców: pozostałość pułku chorążego mozyrskiego Józefa Budziłły - 88 lub 96 osób - została przywieziona do Możajska dopiero w kwietniu 1619 roku (do Wiaźmy zostali przetransportowali dopiero 31 maja) [6, л. 286 об.]. Prócz Budziłly oraz rotmistrzów Erazma Strawińskiego (brata Baltazara), Alberta Podbielskiego (Podbilskiego) i Wołynieckiego (Włonieckiego) grupa składała się z 41 szlachciców oraz 49 pachołków (w tym sześciu kobiet i trojga dzieci) [6, л. 286 об.-288]. Były to niedobitki pułku, który w 1612 roku liczył ok. 1500 żołnierzy (nie licząc cywilów). Bez wątpienia tak znaczny ubytek był wynikiem strat bojowych i klęski głodu w czasie obrony Moskwy w 1612 roku, ale w przeważającej mierze krwawej rozprawy, jaką żołnierzom Budziłły i ich służbie pułkowej po kapitulacji zgotowali kozacy z pierwszego pospolitego ruszenia. Swoje zrobiły też ciężkie warunki niewoli: o ile żołnierzy i służbę z pułku Strusia przez cały czas przetrzymywano w zasobnej Moskwie (dowódców na Kremlu, służbę pułkową, w tym rzemieślników, w gospodarstwach znaczniejszych wielmożów moskiewskich), o tyle podkomendni Budziłły zostali osadzeni w reżimie więziennym $\mathrm{w}$ miastach na prowincji (m.in. w Niżnym Nowogrodzie, Bałachnie, Jarosławlu i Jadrynie).

Taka dyslokacja obydwu grup jenieckich miała prozaiczne powody. Przetrzymywanie blisko dwustu jeńców w jednym miejscu nastręczyłoby 
niepotrzebnych problemów logistycznych. Kluczową była jednak kwestia bezpieczeństwa. Grupę Strusia osadzono w dwóch miejscach w Wiaźmie: starostę chmielnickiego ze służbą $\mathrm{i}$ rotmistrzami umieszczono $\mathrm{W}$,верхнемъ в меншом остроге" tj. w celach męskiego klasztoru Dziecięcia Zbawiciela, znajdującego się w obrębie dworu wojewódzkiego. Nadzór nad nimi powierzono pristawowi Siergiejowi Streszniewowi i sotnikowi strzeleckiemu Jakowowi Dukowowi oraz 75 strzelcom. Resztę grupy, pod opieką pristawa Nieustroja Kusznikowa i głowy strzeleckiego Niesmiejana Żochowa, oraz 75osobowego oddziału strzeleckiego, umieszczono w żeńskim klasztorze Illi Proroka [3, с. 85; 6, л. 23].

Wielcy posłowie nakazali:

«...приказали им быти у литовских людей с великим береженьем. А вяземскому воеводе князю Семену Гагарину приказали для береженья по городу поставити сторожи частые. А для кормовые покупки приказали приставом литовских людей пущати на торг с стрелцы по человеку или по два, а болши того для покупки литовских людей пущати не велели. И того б в торгу стрелцы смотрили и берегли накрепко, чтоб литовские люди в торгу ни с кем не сходились и ни о чом не розговаривали, и сабель бы и пищалей и топоров и ножей и зелья и иного никоторого железа и никаких железных снастей литовским людем покупати не давати» [6, л. 23-23 об.].

Zapewne podobnym reżimem została objęta w Możajsku grupa jeniecka Budziłły.

A powodów do takich środków ostrożności było wiele. W tym czasie z Moskwy zbiegli szlachcice Jan Kamiński i Andrzej Przesiecki: przez jakiś czas przetrzymywano ich w ostrym reżimie więziennym, jednak gdy zgłosili chęć przejścia na służbę carską i „przysięgli na krzyż” nadzór nad nimi zelżał. Skorzystali więc z okazji i uciekli do Dorohobuża, gdzie złożyli obszerne zeznania, jakoby w nieludzkich warunkach przetrzymuje się w Moskwie grupę kilkudziesięciu polskich i litewskich jeńców [6, л. 335 об.-336; 7, л. 20-21].

Sprawa wyglądała na poważną, bo wychodziło na to, że Moskwicini łamią warunki rozejmu i nie chcą wypuścić z niewoli wszystkich jeńców. Do momentu wymiany jenieckiej z tego powodu oraz rzekomej sprzedaży polskolitewskich jeńców tatarom Gosiewski czynił im zarzuty. Groził też zerwaniem negocjacji proceduralnych i wstrzymaniem wymiany jenieckiej. Rzecz jasna z jego strony była to chytra zagrywka mająca osłabić ich pozycjęnegocjacyjną $\mathrm{w}$ grze $-\mathrm{z}$ jego punktu widzenia - o wiele ważniejszej: wzruszeniu postanowień rozejmu w sprawie - zaniedbanych przez Lwa Sapiehę i niego - warunków obrotu gospodarczego na rubieży trubczewsko-nowogrodzko-siewierskobriańskiej oraz przebiegu granicy na rubieży wielisko-toropieckiej, gdzie od czasów Zygmunta Augusta znajdowały się dobra rodowe KorwinGosiewskich [6, л. 437-445].

Jednak rzeczywistość była prozaiczna: strona moskiewska dopiero ściągała jeńców z oddalonych grodów na prowincji, w tym z Syberii, a tych, których udało się już ściagnąć do stolicy wcale nie przetrzymywano w warunkach więziennych. Prawda, były one dalekie od „sanatoryjnych”, ale administracja moskiewska starała się ulżyć ich niedoli, aby „nie marli z głodu i chorób". Przykład z brzegu: w czerwcu 1619 roku car polecił wzniesienie w moskiewskim Kitajgrodzie specjalnego budynku, w którym polsko-litewscy jeńcy przemieszkiwaliby przed wyekspediowaniem do ojczyzny [7, л. 22]. Zresztą w źródłach moskiewskich z lat 1617-1619 brak informacji o pastwieniu się nad jeńcami, są za to wzmianki o ludzkim traktowaniu ich przez moskiewskich nadzorców, np. wysłanego z Bałachny do Moskwy w październiku 1617 roku «пана опалного Ларку, что взят в Девичье монастыре, дано ему по указу от него Прокофью Чюркину на подводу полтину; да на него же куплено шубенко да штанишка, да онучи дано десеть алтын» [2, с. 163].

Zresztą po stronie polsko-litewskiej było nie lepiej. Straty w ludziach, które strona moskiewska poniosła latem 1618 roku w wyniku niszczycielskiej ekspedycji armii kozackiej Piotra KonaszewiczaSahajdacznego były przerażające. Zabitych, ale przede wszystkim uprowadzonych były tysiące. Wprawdzie jeszcze w grudniu 1618 roku komisarze Lew Sapieha i biskup kamienieckiAdam Nowodworski zaapelowali do ,pana hetmana [Konaczewicza-Sahajdacznego], panów pułkowników, asaułów, atamanów i wszytkiego rycerstwa wojska Króla Jego Mości zaporoskiego, ŕbyście wasz mościowie więźnie wszytkie Moskwę, któreście waszmościowie na Liwnie, na Jelcu i na inszych zamkach pobrali, tak narodu zacnego jako i proste ludzie pooddawali Moskwie, 
bo też oni nasze nam oddają według postanowienia naszego i umowy z moskiewskiemi posłami”, jednak był to głos wołającego na puszczy [5, л. 1-2 об.] A i król oraz panowie senatorowie świeccy, tem bardziej duchowni - z oczywistych powodów - nie mogli nic w tej sprawie wskórać. Niestety losów tych nieszczęśników nie znamy: zapewne część z nich powróciła do ojczyzny, jednak większość została w Rzeczypospolitej obrócona $\mathrm{w}$ niewolną siłę roboczą. $\mathrm{Z}$ pewnością także jakaś ich część została wyekspediowana na targi niewolników na Krym i do Turcji.

Mimo wzmożonego nadzoru nad polskolitewskimi jeńcami w Wiaźmie i Możajsku władze moskiewskie zadbały o zabezpieczenie ich pobytu. Dyrektywa z Moskwy brzmiała jednoznacznie:

«А велено из тех запасов давати на корм Струсу с товарыщи понеделно как пригож и мочно им сытим быть» [6, л. 92 об.].

Grupy zostały zaopatrzone w prowiant przywieziony z Moskwy, którego dystrybucja była w gestii wielkich posłów. Prócz tego - według płci i wieku - każdemu jeńcowi przysługiwało, według stawek moskiewskich, dzienne strawne, czyli pieniądze na wyżywienie (tzw. kormowyje diengi): mężczyznom - po ałtynie, kobietom - po cztery diengi, dzieciom - po trzy diengi [6, л. 34]. $\mathrm{Z}$ początku wszystko szło według planu, jednak opóźniająca się wymiana jeniecka i drożyzna na targach w Wiaźmie i Możajsku - ceny były średnio wyższe o $25 \%$ od moskiewskich - szybko zagroziły do niewypłacalnością skarbca polowego wielkich posłów [6, л. 99 об.-100 об.] Problemem był też deficyt produktów żywnościowych szczególnie w Wiaźmie. W tej sytuacji Szeremietiew i Mezecki, w porozumieniu z Moskwą, w następujący sposób zaradzili problemowi:

«Да у старцав, которые присланы к преосвященному митрополиту Филарету Никитичю, у соловецкого старца Моисея да у чюдовского старца у Никандра велено взять литовским людем на корм сто рублев. А как то сто рублев в росход выдет, и у них велено взять литовским людем на корм другую сто рублев. Да ис тех денег велено дать Струсу к прежним к тритцати рублем в займы дватцать рублев до розмены, а на розмене у него те денги пятдесят рублев велено взять».
To pozwoliło wydatnie podnieść jeńcom stawki żywieniowe [6, л. 145 об.-147].

Kłopoty jednak zaczął sprawiać Struś: z wiosną zaczęła mu doskwierać podagra, brakowało mu pełnowartościowej strawy, mięso bez przypraw śmierdziało, a za skromne strawne nie mógł zaopatrzyć się w alkohol. Zwrócił się więc do wielkich posłów o udzielenie kredytu 50 rubli. Ci zaś, po konsultacjach z Moskwą, wsparli go 30 rublami, a następnie brakującymi 20 rublami (do zwrotu w czasie wymiany jenieckiej) [6, л. 95 об.-96 об., 98, 106 об.-107, 145 об.-147], a ze stolicy przysłano obfity transport wiwendy:
«100 полоть ветчины,
15 стягов говядины соленой,
5 четвертей круп овсяных,
2 четверти круп грешневых,
3 четверика гороху,
12 четвериков муки ржаные,
3 четверти муки пшеничные,
7 пудов соли» [6, л. 92].

Dodać do tego należy przysłany z Moskwy specjalnie dla Strusia transport mocnych trunków i przypraw:

«2 ведра раманей, 2 ведра ренского, 3 фунта перцу, пол фунта шафрану, 2 фунта инбирю, фунт гвоздики, голова сахару» [6, л. 164, 177 об.].

Słowem, żyć nie umierać. Rozmiar transportu wskazuje, że był przeznaczony dla całej jego podgrupy Strusia z klasztoru Dziecięcia Zbawiciela. Tak czy inaczej, szczególnie objętość mocnych trunków ,z carskiej ręki” to nie był najlepszy pomysł.

13 maja do Wiaźmy przybył Andrzej Sulemirski, sługa Strusia, którego Moskwicini zwolnili z niewoli kilka miesięcy wcześniej, aby „pilotował" kwestię doprowadzenia do wymiany jenieckiej. Tak więc w czasie tej misji oficjalnie pełnił funkcję gońca, ale też wysłannika żony Strusia - Zofii, która swoją stanowczą postawą na sejmie odbywającym się w Warszawie 22 stycznia - 5 marca 1619 roku w znacznym stopniu wpłynęła na króla i senatorów, aby przyspieszyli wymianę jeńców [6, л. 174 об.; 9, c. 77-80]. Zresztą wyglądało na to, że to krewnym i powinowatym jeńców, a nie elitom Rzeczypospolitej, zależało na jak najszybszym sfinalizowaniu całej sprawy: m.in., prócz 
Strusiowej, Baltazarowi Strawińskiemu oraz najbliższym Budziłły, np. Janowi Kunowskiemu, zaufanemu Gosiewskiego. Dowodem na to jest przybycie Lwa Sapiehy dopiero dwa tygodnie po rozpoczęciu obrad i podjęcie tematu rozejmu dywilińskiego - uwaga! - 3 marca, a więc na dwa dni przed zakończeniem sejmu. Wtedy to król i część senatorów zaatakowała kanclerza litewskiego nie tylko za jego machinacje podczas rokowań przed i w trakcie negocjacji rozejmowych w listopadzie i grudniu 1618 roku wycofał z Wiaźmy oddział kozaków zaporoskich, przeznaczonych do ochrony poczty dyplomatycznej, zrywając komunikację z Warszawą - ale także za niekorzystne warunki rozejmu (m.in. odesłanie praw królewicza na „sąd Boży”) [9, c. 77-80; 8, c. 442-444; 6, л. 346-348].

W geście dobrej woli wielcy posłowie zezwolili na osobiste spotkanie Sulemirskiego ze Strusiem i jego oficerami, jednak pod nadzorem pristawów. I nie był to dobry pomysł. Mocno wstawiony starosta chmielnicki zażądał, aby Sulemirski mógł przenocować u niego, a wobec sprzeciwu nadzorców, zaczął łajać ich „grubymi słowami". Wielcy posłowie byli obrażeni, ale Sulemirskiemu udało się całą sprawę załagodzić, pokrętnie thumacząc, że «Струс де и не пьян, и он человек сердитой, а как де изопьет, и он де в те поры и всего забудет, - чтоб де вам, бояром, для ево, Андреева, прошенья над Струсом смиловатца и поволить бы ему, Ондрею, к Струсу отписати от себя сегодни вечере, как он вытрезвеет» [6, л. 196].

Do drugiego wyskoku pijanego Strusia doszło krótko przed wymiana jeniecką. 6 czerwca do Wiaźmy przyjechał goniec Jan Kunowski, któremu wielcy posłowie umożliwili spotkanie $\mathrm{z}$ nim. Oto relacja z niego:

«И Пимин Юшков и литовской гонец Ян Куновской и подьячей и переводчик пришол на зьезжей двор и бояром сказывали что они к Струсу ходили. И как де Куновской пришол к Струсу и Струсь де стоит в ызбе пьян, и Куновской де правил ему челобитье от послов от Олександра Гасевского и от Балтазара Стравинского. И Струсъ де ему, Куновскому, и Пимину Юшкову и приставом велел сесть, и, посидя, де Пимин Юшков говорил Струсу, что царского величества бояря дождаютца ево, Куновского, к отпуску и он бы его не задержал. И Струсь де ево, Пимина, зашиб по щеке, а пристава Сергея Стрешнева зашиб в груди. И Куновской де, встав, от него, от Струса, пошол с ними вон, а Пимин де и Сергей учали Струсу говорить: царского величества бояре жалели тебя, Струса, и, оказуя во всем к тебе свою добродетель и любовъ и приятелство, присылают литовских гонцов с тобою видетца, и к тебе по ся места держит во всем честь и ласку. А ты, напився пьян, так дуруешъ и нас, царского величества дворян, позоришъ. Нам с тобою дратца - не честь, а кликнем с караула стрелцов и велим опозорить самово - и тебе то какая честь будеть, коли уже ты сам над собою чести держать не умеешъ! Завтра ж тебе тесноты прибудет, и вперед так напиватца и дуровать не учнешь. И Струс де учал сердитовать и порывался за саблю. И Ян Куновской сказывал те ж речи и говорил: мы де его давно и в Литве знаем - как напьетца, и он де не ведает, что с сердца делает, и яз де одва ушол, и не говорил с ним ничего».

Tym razem wojewodowie nie byli pobłażliwi: służbie Strusia nie tylko zabroniono dokonywania zakupów na targu i w karczmie, ale opuszczania murów klasztoru, a na wszystkie zaczepki Strusiowych pachołków strzelcom bezwzględnie nakazano siłą wymuszać posłuch [6, л. 360-361].

Zbliżała się wymiana jeniecka. Od połowy marca obie strony ustaliły jej procedurę: $\mathrm{w}$ wyniku wizji lokalnej uzgodniono miejsce - na równinie nad rzeczką Polanówką, rozciagającą się na północ od traktu wiaziemsko-dorohobuskiego [6, л. 239 об.-240]. Posłom i jeńcom miało asystować po 500 żołnierzy. Do wymiany miało dojść 10 czerwca [6, л. 376 об.-378].

Jednak do ostatniej chwili atmosfera była napięta, bo łamiąc ustalenia Gosiewski próbował wymusić na Szeremietiewie zmianę warunków rozejmu dywilińskiego dotyczących przebiegu granicy na rubieży wielisko-toropieckiej oraz ułatwienia w przekraczania granicy dla kupców polsko-litewskich i moskiewskich na rubieży trubczewsko-nowogrodzko-siewiersko-briańskiej. Problem w tym, że car i urząd poselski, licząc się z niespodziankami ze strony przebiegłego Litwina, w instrukcji poselskiej nakazali Szeremietiewowi ograniczyć swój udział w wymianie jedynie do przejęcia i powitania Filareta Nikitycza. Podjęcie reszty jeńców leżało w gestii księcia Mezeckiego i diaków. Początkowo Szeremietiew twardo odrzucał żądania Gosiewskiego podjęcia dodatkowych negocjacji, że nie godzi się mu pertraktować z chudorodnym urzędnikiem. Gosiewski na to, że on «у государя их короля человек чесной и пан равной и вашим де бояром за што с ним не съезжатца» [6, л. 373 об.], 
a wobec dalszych oporów Szeremietiewa zagroził wstrzymaniem wymiany. Udało się mu też urobić niezorientowanego w bieżących wydarzeniach Filareta Nikitycza, że opóźniająca się wymiana jeniecka to wynik opieszałości wielkich posłów. W końcu szantaż Gosiewskiego i presja metropolity rostowskiego wobec Szeremietiewa, aby nie ryzykował jego i syna gniewu, zrobiła swoje [6, л. 437-445].

Sama procedura wymiany - przejście grup po dwóch mostach przerzuconych przez Polanówkę - odbyła się w późnych godzinach wieczornych [6, л. 449-452]. Grupę moskiewską stanowily 272 osoby, podzielone na dwie kategorie: więźniów, czyli członków poselstwa, które na czele z Filaretem Nikityczem zostało po fiasku rokowań pod Smoleńskiem jesienią 1610 internowane $\mathrm{w}$ Rzeczypospolitej, oraz jeńców, na czele z wojewodą Michaiłem Szeinem, który znaleźli się w polsko-litewskiej niewoli po zdobyciu Smoleńska w czerwcu 1611 roku [6, л. 400 об.404 об.]. W czasie wymiany strony wymieniły się listami imiennymi jeńców, których repatriacja miała nastąpić do końca roku [6, л. 409 об.419 об., 425-426 об.]. Np. kilka dni po wymianie nad Polanówką Moskwicini zwolnili kilkudziesięciu żołnierzy i pachołków na czele $\mathrm{z}$ rotmistrzem Andrzejem Młockim [6, л. 456-462].

\section{СПИСОК ЛИТЕРАТУРЫ}

1. Дело об отдаче в силу Деулинского договора в польскую сторону городов Новгорода Северского, Трубчевска, города Красного городища, Себежа, Невля Стародуба и Почепа со всем пушечным снарядом и пр., январь - март 1619 г. // Российский государственный архив древних актов (РГАДА). - Ф. 79. Сношения с Польшей. - Оп. 1.Реестр 2. Столбцы Польского стола Посольского приказа. - 1619. - Д. 2.

2. Сироткин, С. В. Один год из жизни Балахны (по материалам приходо-расходных книг земских старост 1617/1618) / С. В. Сироткин // Народные ополчения и российские города в Смутное время начала XVII века : материалы Всерос. науч. конф., г. Балахна Нижегородской области, 6-7 окт. 2011 г. Н. Новгород : Комитет по делам архивов Нижегородской области, 2012. - С. 121-182.

3. Смирнова, А. Т. Формирование архитектурного облика Вязьмы в XVI-XVII вв. / А. Т. Смирнова // Вязьма. Страницы истории : материалы краевед. конф. 2001-2004 гг.-Смоленск: [б. и.], 2005.-С. 83-92.
4. Списки всех договорных записей, заключенных в Троицкой деревне Деулине между российскими послами боярином Федором Шереметьевым и пр. с польскими послами князем Адамом Новодворским и пр. о перемирии на 14 лет с половиною, 1 декабря 1618 г. - 1 июня 1619 г. // РГАДА. Ф. 79. Сношения с Польшей. - Оп. 1. - Реестр 1. Книги Польского стола Посольского приказа. Кн. 35.

5. Статейный список Российских послов боярина Федора Шереметьева, князя Данила Мезецкого с товарищи, бывших на съезде на речке Поляновке с польскими послами Александром Гасевским и прочими для размена пленных и всякого чина и звания людей, а особлив Ростовского митрополита Филарета и боярина Шейна, февраль - апрель 1619 г. // РГАДА. - Ф. 79. Сношения с Польшей. Оп. 1. - Реестр 2. Столбцы Польского стола Посольского приказа. 1619. - Д. 3.

6. Статейный список русских послов боярина Федора Шереметьева, князя Данила Мезецкого и прочих чинов, бывших на съезде на речке Поляновке для размена пленных с обеих сторон, а паче митрополита Ростовского Филарета Никитича и для учинения с бывшими тут же польскими послами Александром Госевским, референдарем и писарем литовским с товарищи договорной записи о высылке остальных пленных, об отсрочке межевых судей и пр. // РГАДА. - Ф. 79. Сношения с Польшей. Реестр 1. - Оп. 1. Книги Польского стола Посольского приказа. - Кн. 38.

7. Челобитные разных чинов Посольского приказа людей о пожаловании за службу в посольствах, полонское терпение и на оные данные грамоты // РГАДА. - Ф. 141. Приказные дела старых лет. - Оп. 1. - Связка 7. - 1619-1621. - Д. 5.

8. Czwołek, A. Piórem i buławą. Działalność polityczna Lwa Sapiehy, kanclerza litewskiego, wojewody wileńskiego / A. Czwołek. - Toruń : Wydawnictwo Naukowe Uniwersytetu Mikołaja Kopernika, 2012. - 734 s. + 14 il.

9. Rzońca, J. Ostatni sejm przed Cecora (w 1619 r.). Pamiętnik Biblioteki Kórnickiej/ J. Rzońca. 1983. - Z. 20. - Wrocław; Warszawa; Kraków; Gdańsk; Łódź : Zakład Narodowy im. Ossolińskich. Wydawnictwo Polskiej Akademii Nauk, 1983. - 92 s.

\section{REFERENCES}

1. Delo ob otdache v silu Deulinskogo dogovora v polskuyu storonu gorodov Novgoroda Severskogo, Trubchevska, goroda Krasnogo gorodishcha, Sebezha, Nevlya Staroduba i Pochepa so vsem pushechnym snaryadom i pr., yanvar - mart $1619 \mathrm{~g}$. [The Document on the Transfer of Novgorod-Seversky, Trubchevsk, 
Krasnoe Gorodishche, Sebezh, Nevlya Starodub and Pochep Cities with Main Guns, etc., January - March 1619]. Rossiyskiy gosudarstvennyy arkhiv drevnikh aktov [Russian State Archive of Ancient Acts], F. 79. Snosheniya s Polshey [Relations with Poland], Op. 1, Register 2. Stolbtsy Polskogo stola Posolskogo prikaza. 1619 [Columns of the Polish Stol of the Ambassadorial Prikaz. 1619], D. 2.

2. Sirotkin S.V. Odin god iz zhizni Balakhny (po materialam prikhodo-raskhodnykh knig zemskikh starost 1617/1618) [One Year from the Life of Balakhna (on the Materials of Account Books of Zemstvo Heads of 1617/1618)]. Narodnye opolcheniya $i$ rossiyskie goroda $v$ Smutnoe vremya nachala XVII veka: materialy Vseros. nauch. konf., $g$. Balakhna Nizhegorodskoy oblasti 6-7 okt. $2011 \mathrm{~g}$. [Folk Militias and Russian Cities in the Time of Troubles of the Early $17^{\text {th }}$ Century. Materials of the All-Russian Scientific Conference, Balakhna, Nizhny Novgorod Region, October 6-7, 2011]. Nizhny Novgorod, Komitet po delam arkhivov Nizhegorodskoy oblasti, 2012, pp. 121-182.

3. Smirnova A.T. Formirovanie arkhitekturnogo oblika Vyazmy v XVI-XVII vv. [Formation of the Architectural Appearance of Vyazma in the $16^{\text {th }}-17^{\text {th }} \mathrm{c}$.]. Vyazma. Stranitsy istorii: materialy kraevedcheskikh konferentsiy 2001-2004 gg. [Vyazma. Pages of History. Proceedings of Local History Conferences 2001-2004]. Smolensk, 2005, pp. 83-92.

4. Spiski vsekh dogovornykh zapisey, zaklyuchennykh v Troitskoy derevne Deuline mezhdu rossiyskimi poslami boyarinom Fedorom Sheremetevym i pr. s polskimi poslami knyazem Adamom Novodvorskim i pr. o peremirii na 14 let s polovinoyu, 1 dekabrya 1618 g. - 1 iyunya 1619 g. [Lists of all Contractual Records Concluded in Deulino Trinity Village between Russian Ambassadors Boyar Fyodor Sheremetyev and Others with Polish Ambassadors Prince Adam Novodvorsky and Others on the Truce for 14 Years and a Half, December 1, 1618 - June 1, 1619]. Rossiyskiy gosudarstvennyy arkhiv drevnikh aktov [Russian State Archive of Ancient Acts], F. 79. Snosheniya s Polshey [Relations with Poland], Op. 1, Register 1. Knigi Polskogo stola Posolskogo prikaza [Books of the Polish Stol of the Ambassadorial Prikaz], Book 35.

5. Stateynyy spisok Rossiyskikh poslov boyarina Fedora Sheremeteva, knyazya Danila Mezetskogo s tovarishi, byvshikh na syezde na rechke Polyanovke s polskimi poslami Aleksandrom Gasevskim i prochimi dlya razmena plennykh i vsyakogo china i zvaniya lyudey, a osobliv Rostovskogo mitropolita Filareta i boyarina Sheyna, fevral - aprel 1619 g. [Record List of Russian Ambassadors Boyar Fyodor Sheremetev, Prince Danil
Mezetsky and Comrades Who Were at the Meeting at the Polyanovka River with Polish Ambassadors Alexander Gasevsky and Others for Exchanging Captives and People of All Ranks, and Especially Rostov Metropolitan Filaret and Boyar Sheyn, February - April 1619]. Rossiyskiy gosudarstvennyy arkhiv drevnikh aktov [Russian State Archive of Ancient Acts], F. 79. Snosheniya s Polshey [Relations with Poland], Op. 1, Register 2, Stolbtsy Polskogo stola Posolskogo prikaza [Columns of the Polish Stol of the Ambassadorial Prikaz], 1619, D. 3.

6. Stateynyy spisok russkikh poslov boyarina Fedora Sheremeteva, knyazya Danila Mezetskogo i prochikh chinov, byvshikh na syezde na rechke Polyanovke dlya razmena plennykh s obeikh storon, a pache mitropolita Rostovskogo Filareta Nikiticha i dlya uchineniya s byvshimi tut zhe polskimi poslami Aleksandrom Gosevskim, referendarem i pisarem litovskim s tovarishchi dogovornoy zapisi o vysylke ostalnykh plennykh, ob otsrochke mezhevykh sudey i pr. [Record List of Russian Ambassadors Boyar Fyodor Sheremetev, Prince Danil Mezetsky and Other Officials Who Were at the Meeting at the Polyanovka River for Exchanging Captives on Both Sides, and Especially Rostov Metropolitan Filaret Nikitich, and for Signing a Contractual Record on the Dispatch of the Rest Captives, on the Delay of Boundary Judges, etc. with Former Polish Ambassadors Alexander Gosevsky, Referendary and Lithuanian Clerk with Comrades]. Rossiyskiy gosudarstvennyy arkhiv drevnikh aktov [Russian State Archive of Ancient Acts], F. 79. Snosheniya s Polshey [Relations with Poland], Register 1, Op. 1, Knigi Polskogo stola Posolskogo prikaza [Books of the Polish Stol of the Ambassadorial Prikaz], Book 38.

7. Chelobitnye raznykh chinov Posolskogo prikaza lyudey o pozhalovanii za sluzhbu v posolstvakh, polonskoe terpenie i na onye dannye gramoty [Petitions of Various Ranks of the Ambassadorial Prikaz People on the Award for Service in Embassies, Being in Captivity and for These Documents]. Rossiyskiy gosudarstvennyy arkhiv drevnikh aktov [Russian State Archive of Ancient Acts], F. 141. Prikaznye dela starykh let [Office Affairs of Old Years], Op. 1, Svyazka 7. 16191621, D. 5.

8. Czwołek A. Piórem i buławq. Działalność polityczna Lwa Sapiehy, kanclerza litewskiego, wojewody wileńskiego. Toruń, Wydawnictwo Naukowe Uniwersytetu Mikołaja Kopernika, 2012. 734 p. +14 il.

9. Rzońca J. Ostatni sejm przed Cecorq (w 1619 r.). Pamiкtnik Biblioteki Kyrnickiej. 1983. Z. 20. Wrocław; Warszawa; Kraków; Gdańsk; Łódź, Zakład Narodowy im. Ossolińskich. Wydawnictwo Polskiej Akademii Nauk, 1983. 92 p. 


\section{Information about the Author}

Tomasz Bohun, PhD, Editor of "Mówią wieki” (Centuries Speak) Science History Magazine, Europian Sq., 3, 00-844 Warsaw, Poland, bohuntomasz@gmail.com, https://orcid.org/0000-0002-2051-5648

\section{Информация об авторе}

Томаш Бохун, $\mathrm{PhD}$, редактор исторического журнала «Говорят столетия» («Mówią wieki»), Европейская площадь, 3, 00-844 г. Варшава, Республика Польша, bohuntomasz@gmail.com, https://orcid.org/0000-0002-2051-5648

\section{Informacje o autorze}

Tomasz Bohun, PhD, redaktor czasopisma historycznego Mówią wieki, Europejska pl., 3, 00-844 Warszawa, Rzeczpospolita Polska, bohuntomasz@gmail.com, https://orcid.org/0000-0002-2051-5648 